\title{
Corporate Social Responsibility Dalam Value Perusahaan Dengan Profitabilitas Dan Ukuran Perusahaan Sebagai Variabel Moderating
}

\author{
Muchamad Taufiq \\ STIE Widya Gama Lumajang \\ muchamadtaufiamh@gmail.com
}

\begin{abstract}
Abstrak
Tujuan Penelitian ini untuk mengetahui apakah Corporate Social Responsibility memiliki korelasi terhadap nilai perusahaan dengan profitabilitas dan ukuran perusahaan sebagai variable moderang. Penelitian ini didasari oleh teori yang menyatakan bahwa naik turunnya nilai perusahaan dipengaruhi oleh pelaporan Corporate Social Responsibility terhadap publik dan variable proritabilitas serta ukuran perusahaan yang di anggap mampu mempengaruhi nilai perusahaan ketika pelaporan Corporate Social Responsibility terhadap nilai perusahaan menurun dan meningkat. Penelitian ini merupakan penelitian kuantitatif dalam bentuk pengujian hipotesis. Metode yang digunakan dalam penelitian ini adalah metode statistic deskriptif, Penelitian ini menggunakan sumber data eksternal dengan jenis data sekunder yang diperoleh dari laporan keuangan yang diterbitkan oleh perusahaan yang terdaftar di Bursa Efek Indonesia (BEI),. Adapun uji yang dilakukan dalam penelitian ini adalah uji analisis data dan uji signifikansi hipotesis serta uji penelitian yang menggunakan regresi linier berganda. Hasil penelitian menunjukkan Corporate Social Responsibility korelasi positif terhadap value perusahaan dengan signifikansi 0,012 . Profitabilitas sebagai variable moderating 1 juga mempengaruhi Corporate Social Responsibility dan nilai perusahaan dengan nilai signifikansinya sebesar 0,048 . Ukuran perusahaan sebagai variable moderating 2 dianggap berkorelasi positif terhadap Corporate Social Responsibility dan value perusahaan dengan nilai signifikansi sebesar 0,049.
\end{abstract}

Kata kunci: Corporate Social Responsibility, Nilai Perusahaan, Profitabilitas, dan ukuran perusahaan.

\section{Abstract}

This study aims to determine whether the Corporate Social Responsibility affect the value of the company to profitability and the size of the company as variable moderang. This study is based on the theory that the rise and fall in value is influenced by the reporting company's Corporate Social Responsibility towards the public and variable proritabilitas well as the size of company that is considered capable of affecting the value of the company as Corporate Social Responsibility reporting to company value decreases and increases. This research is a quantitative research in the form of hypothesis testing. The method used in this research is descriptive statistical methods, this study uses an external data source with secondary data obtained from the financial statements issued by companies listed on the Indonesian Stock Exchange (BEI),. The test in doing this research is the analysis of test data and test hypotheses and test the significance of studies using multiple linear regression. The results showed Corporate Social Responsibility positive effect on firm value with significance 0.012. Profitability as a moderating variable 1 does affect the Corporate Social Responsibility and the value of the company the significance value of 0.048. The size of the company as a moderating variable 2 is considered a positive influence on Corporate Social Responsibility and the value of the company with a significance value of 0.049. This research is consistent with prior research as explained in the discussion.

\section{Keywords: Corporate Social Responsibility, Corporate Value, Profitability, and firm size.}

\section{PENDAHULUAN}

CSR atau tanggung jawab sosial perusahaan merupakan suatu bentuk tanggung jawab yang dilakukan perusahaan terhadap lingkungan sekitarnya atau ruang lingkup terkait di dalam memperbaiki kesenjangan sosial dan kerusakan-kerusakan lingkungan yang terjadi akibat dari aktivitas operasional perusahaan. Semakin tinggi keperdulian tanggung jawab sosial yang di lakukan perusahaan terhadap lingkungannya, maka menurut pandangan masyarakat image perusahaan akan semakin meningkat dan citra perusahaan menjadi lebih baik. Investor lebih berminat pada perusahaan yang memiliki citra yang baik di masyarakat karena semakin baik citra perusahaan, maka loyalitas konsumen semakin tinggi. Seiring meningkatnya loyalitas konsumen dalam waktu lama maka penjualan perusahaan akan membaik dan pada akhirnya di harapkan tingkat prifitabilitas perusahaan juga meningkat. Jika perusahaan berjalan lancar, maka nilai saham perusahaan akan meningkat. Secara teoritis suatu perusahaan di katakan mempunyai nilai baik jika kinerja perusahaan juga baik. Nilai perusahaan dapat tercermin dari harga sahamnya, apabila nilai sahamnya tinggi bisa di katakan nilai perusahaannya juga baik karena tujuan utama perusahaan adalah 
meningkatkan nilai perusahaan melalui peningkatan kemakmuran pemilik atau pemegang saham (Rimba Kusumadilaga, 2010.

Corporate Social Responsibility saat ini bersifat wajib bagi beberapa perusahaan untuk melakukan atau menerapkannya. Hal ini di atur dalam Undang-Undang Nomor 40 Tahun 2007 tentang Perseroan Terbatas (UUPT), yang di sahkan pada 20 Juli 2007. Sedangkan sanksi pidana mengenai pelanggaran CSR pun terdapat di dalam Undang-Undang Nomor 23 Tahun 1997 tentang Pengelolaan Lingkungan Hidup (UUPLH) pasal 41.

Pengungkapan Corporate social responsibility pada dasarnya dilandasi oleh adanya stakeholder dan legitimasi theory. Teori stakeholder menyatakan bahwa perusahaan bukanlah entitas yang hanya beroperasi untuk kepentingan sendiri namun harus memberi manfaat bagi stakeholder-nya, sementara pada legitimacy theory perusahaan dikatakan memiliki kontrak dengan masyarakat untuk melakukan kegiatannya berdasarkan nilai-nilai justice. Kamus online Wikipedia mendefinisikan CSR sebagai suatu konsep bahwa suatu organisasi memiliki kewajiban untuk memperhatikan kepentingan pelanggan, karyawan, pemegang saham, komunitas dan pertimbangan-pertimbangan ekologis dalam segala aspek dari usahanya. CSR berhubungan erat dengan pembangunan berkelanjutan, dimana ada argumentasi bahwa suatu perusahaan dalam melaksanakan aktivitasnya harus mendasarkan keputusannya tidak semata berdasarkan faktor keuntungan melainkan juga harus berdasarkan konsekuensi sosial dan lingkungan untuk saat ini maupun jangka panjang. Corporate Social Responsibility dapat di gunakan sebagai alat marketing baru bagi perusahaan bila itu dilaksanakan berkelanjutan.

Menurut Analisa (2011) dalam Ayu Sri Mahatma Dewi dan Ary Wirajaya (2013) nilai perusahaan dapat pula dipengaruhi oleh besar kecilnya profitabilitas yang di hasilkan oleh perusahaan. Profitabilitas adalah kemampuan suatu perusahaan untuk menghasilkan laba selama periode tertentu, rasio profitabilitas adalah kemampuan perusahaan memperoleh laba dalam hubungannya dengan penjualan, total aktiva maupun modal sendiri.

Selain tanggung jawab sosial perusahaan, ukuran perusahaan dianggap mampu mempengaruhi nilai perusahaan. Menurut Bhekti Fitri Prasetyorini (2013) terdapat banyak faktor yang dapat menentukan nilai perusahaan, salah satunya adalah ukuran perusahaan. Ukuran perusahaan adalah salah satu skala dimana dapat diklasifikasikan besar kecilnya perusahaan menurut berbagai caraantara lain dengan total aktiva, log size, nilai pasar saham, dan lain-lain. Ukuran perusahaan di anggap mampu mempengaruhi nilai perusahaankarena semakin besar ukuran perusahaan atau skala perusahaan maka akan semakin mudah pula perusahaan memperoleh sumber pendanaan baik yang bersifat internal maupun eksternal.

Berdasarkan uraian latar belakang diatas peneliti tertarik untuk menguji dan menganalis pengaruh antara variabel-variabel Corporate Social Responsibility, profitabilitas, ukuran perusahaan, dan nilai perusahaan.

\section{KAJIAN PUSTAKA}

\section{Pertanggung Jawaban Sosial Perusahaan}

Pengungkapan tanggung jawab sosial perusahaan yang sering juga disebut sebagai social disclosure, corporate social reporting, social accounting atau corporate social responsibility merupakan proses pengkomunikasian dampak sosial dan lingkungan dari kegiatan ekonomi organisasi terhadap kelompok khusus yang berkepentingan dan terhadap masyarakat secara keseluruhan. Hal tersebut memperluas tanggung jawab organisasi (khususnya perusahaan), di luar peran tradisionalnya untuk menyediakan laporan keuangan kepada pemilik modal, khususnya pemegang saham. Perluasan tersebut di buat dengan asumsi bahwa perusahaan mempunyai tanggung jawab yang lebih luas di banding hanya mencari laba untuk pemegang saham (Hackston \& Milne, 1996 dalam Imam Subekti).

Ada sejumlah faktor yang mendorong dunia usaha melaksanakan aktivitas CSR sebagai bagian dari seluruh aktivitas perusahaan, walau bagi dunia usaha tertentu kegiatan CSR tidak di wajibkan, tetapi masih ada banyak faktor yang mendorong mereka untuk melakukan kegiatan CSR sehingga tidak jarang di jumpai adanya lembaga independen yang memberikan sertifikasi kepada dunia usaha yang telah melakukan berbagai aktivitas kepedulian sosial dan hal itu di anggap dapat menaikkan citra perusahaan sehingga memberikan stimulan bagi dunia usaha itu sendiri, selain itu banyak dunia usaha yang memeperhitungkan bahwa kegiatan CSR yang di lakukan dapat menjadi bagian dan alat promosi pemasaran, dengan demikian mereka justru memasukkan kegiatan CSR ini sebagai bagian integral dan keseluruhan aktivitas bisnisnya.

\section{Teori Stakeholder}

Teori stakeholder merupakan teori yang menjelaskan bagaimana manajemen perusahaan memenuhi atau mengelolah harapan para stakeholder. Teori stakeholder menekankan mengenai akuntabilitas organisasi jauh melebihi kinerja keuangan atau ekonomi sederhana. Teori ini menyatakan bahwa organisasi akan memilih secara sukarela mengungkapkan informasi tentang kinerja lingkungan, sosial dan intelektual mereka, melebihi dan di atas permintaan wajibnya, untuk memenuhi ekspektasi sesungguhnya atau yang diakui oleh stakeholder. Salah satu bentuk pengungkapan sukarela yang berkembang saat ini yaitu publikasi CSR. Melalui publikasi CSR perusahaan dapat memberikan informasi yang lebih cukup dan lengkap 
berkaitan dengan kegiatan dan pengaruhnya terhadap kondisi sosial masyarakat dan lingkungan (Gozali dan Chariri, 2007 dalam Rinaldi, 2011 dalam Ira Agustine,2014)

\section{Teori Legitimasi}

Teori legitimasi merupakan suatu gagasan tentang kontrak sosial antara perusahaan dengan masyarakat. Menurut teori ini, untuk di terima oleh masyarakat, perusahaan harus mengungkapkan aktivitas sosial perusahaan sehingga akan menjamin kelangsungan hidup perusahaan. Teori legitimasi juga berpendapat bahwa perusahaan harus melakusanakan dan menggungkapkan aktivitas CSR semaksimal mungkin agar aktivitas perusahaan dapat diterima oleh masyarakat. Pengungkapan ini dugunakan untuk melegitimasi aktivitas perusahaan di mata masyarakat. Pengungkapan ini di gunakan untuk melegitimasi aktivitas perusahaan di mata masyarakat, karena pengungkapan CSR akan menunjukkan tingkat kepatuhan perusahaan (Branco dan Rodrigues, 2008 dalam Gusti Ayu Made Ervina Rosiana dan Gede Juliarsa, 2013)

\section{Profitabilitas}

Rasio profitabilitas merupakan rasio untuk menilai kemampuan perusahaan dalam mencari keuntungan. Rasio ini juga memberikan ukuran tingkat efektivitas manajemen suatu perusahaan. Hal ini ditunjukkan oleh laba yang di hasilkan dari penjualan dan penddapatan investasi.Intinya bahwa penggunaan rasio ini menunjukkan efisiensi perusahaa. (Kasmir, 2009:115)

\section{Ukuran perusahaan}

Ukuran perusahaan adalah peningkatan dari kekayaan, perusahaan besar akan memiliki kapitalisasi pasar yang besar, nilai buku yang besar dan laba yang tinggu. Sedangkan pada perusahaan kecil akan memiliki kapitalisasi pasar yang kecil, nilai buku yang kecil dan laba yang rendah" (Wedari, 2006 dalam Ayu Sri Mahatma Dewi danAry Wirajaya, 2013)

\section{Nilai Perusahaan}

Nilai perusahaan merupakan harga yang bersedia di bayar oleh calon pembeli andai perusahaan tersebut di jual, enterprise value (EV) atau di kenal juga sebagai film value (nilai perusahaan) merupakan konsep penting bagi investor, karena merupakan indikator bagi pasar menilai perusahaan secara keseluruah" (Nurlela dan Islahuddin, 2008 dalam Imam Subekti)."Nilai perusahaan diartikan sebagai nilai pasar dalam penelitian ini, karena apabila harga saham perusahaan meningkat,maka perusahaan dapat memberikan kemakmuran kepada para stakeholder"(Nurlela dan Islahuddin, 2008 dalam Gusti Ayu Made Ervina Rosiana dan Gede Juliarsa, 2013).

\section{Hipotesis}

$\mathrm{H}_{1}$ : Corporate Social Responsibility berpengaruh positif terhadap nilai perusahaan.

$\mathrm{H}_{2}$ : Corporate Social Responsibility berpengaruh positif terhadap nilai perusahaan ketika profitabilitas perusahaan tinggi.

$\mathrm{H}_{3}$ : Corporate Social Responsibility berpengaruh positif terhadap nilai perusahaan ketika ukuran perusahaan tinggi.

\section{METODE PENELITIAN \\ Obyek Penelitian}

Objek penelitian yang di gunakan dalam penelitian ini adalah Corporate social Responsibility (CSR) terhadap nilai perusahaan dengan variabel moderating profitabilitas dan ukuran perusahaan.

\section{Sumber Dan Jenis Data}

Sumber data yang digunakan dalam penelitian ini adalah sumber data ekternal yang di ambil melalui IDX (www.IDX.co.id), data dalam penelitian ini bersifat sekunder. Jenis data yang di gunakan dalam penelitian ini adalah data kuantitatif yang di peroleh dari sumber-sumber yang berhubungan dengan penelitian yang terdaftar di Bursa Efek Indonesia. Sedangkan data yang digunakan dalam penelitian ini adalah laporan keuangan tahunan perusahaan untuk periode tahun 2011-2014.

\section{Populasi dan Teknik Pengambilan Sampel}

Populasi dalam penelitian ini adalah perusahaan-perusahaan manufaktur makanan minuman yang terdaftar di Bursa Efek Indonesia dengan pemilihan sampel menggunakan metode purposive sampling yang bertujuan untuk mendapatkan sampel yang representatif sesuai dengan kriteria yang di tentukan

\section{Definisi Operasional Variabel}

a. Variabel Independen

Pengukuran instrumen pengungkapan CSR terfokus pada 3 item tersebut di antaraya adalah: lingkungan, produk, dan keterlibatan masyarakat yang terdiri dari 32 item. Pendekatan untuk menghitung pengungkapan CSR menggunakan pendekatan dikotomi yaitu setiap item pengungkapan tanggung jawab sosial dalam instrumen penelitian di beri nilai 1 jika diungkapkan, dan nilai 0 jika tidak diungkapkan. Selanjutnya skor dari setiap item dijumlahkan untuk memperoleh keseluruhan skor untuk setiap perusahaan.

Rumus perhitungan sebagai berikut : 
Keterangan :

CSRlj = pengungkapan Corporate Social Responsibility Index perusahaan j

$\mathrm{n} \quad=$ jumlah skor pengungkapan yang diperoloeh untuk perusahaan $\mathrm{j}$

$\mathrm{k} \quad=$ jumlak skor maksimal

b. Variabel Moderating

- Profitabilitas merupakan variabel moderating yang di simbolkan dengan (X2). "Profitabilitas adalah Return on Assets (ROA) yang di dapat dari laporan keuangan tahunan perusahaan manufaktur makanan dan minuman, selama periode penelitian. ROA menunjukaka perbandingan net income dan total asset perusahaan. Rumus profitabilitas sebagai berikut :

Return on Assets = Earning Before Interest and Tax

\section{Total Aktiva}

- Ukuran perusahaan (X3) dalam penleitian ini di nyatakan dengan total aktiva, "semkin besar total aktiva perusahaan maka akan semakin besar pula ukuran perusahaan itu. Ukuran perusahaan dapat di lihat dari total aset yang dimiliki oleh perusahaan" (Suharli, 2006). Dalam penelitian ini ukuran perusahaan diukur dengan menggunakan log of total assets, Rumus ukuran perusahaan sebagai berikut :

Ukuran perusahaan $=\mathrm{Ln}$. Total Aktiva

c. Variabel Dependen

Nilai perusahaan di simbolkan dengan $(Y)$. Salah satu alternatif yang di gunakan dalam mengukur nilai perusahaan adalah dengan menggunakan Tobin's $Q$. Rasio $Q$ merupakan ukuran yang lebih teliti tentang seberapa efektif manajemen memanfaatkan sumber daya ekonomi dalam kekuasaannya. Rumus rasio $Q$ adalah :

$$
\mathrm{Q}=\frac{(\mathrm{EMV}+\mathrm{D})}{(\mathrm{EBV}+\mathrm{D})}
$$

Keterangan :

Q $\quad$ Nilai perusahaan

$\mathrm{EMV}=$ Nilai pasar ekuitas

$\mathrm{D} \quad=$ Nilai buku dari total hutang

$\mathrm{EBV}=$ Nilai buku dari total ekuitas

\section{Hasil Analisis Data}

Satatistik Deskriptif

Dalam penelitian ini terdapat 5 data outliers, yaitu data yang memiliki nilai ekstrim yang cukup tinggi sehingga 4 data tersebut harus di keluarkan dari penelitian supaya tidak menimbulkan hasil yg bias. Oleh karena itu dari nilai 40 sampel perusahaan hanya 35 sampel yang akan di uji dalam penelitian ini. Statistik deskripti dari data-data dalampenelitian ini di sajikan dalam tabel berikut

\section{Tabel 4.8 Statistik Deskriptif}

Descriptive Statistics
\begin{tabular}{|l|r|r|r|r|r|}
\hline & $\mathrm{N}$ & $\begin{array}{c}\text { Minimu } \\
\mathrm{m}\end{array}$ & $\begin{array}{c}\text { Maximu } \\
\mathrm{m}\end{array}$ & Mean & $\begin{array}{c}\text { Std. } \\
\text { Deviati } \\
\text { on }\end{array}$ \\
\hline CSR & 35 & .5 & .72 & .1909 & .05705 \\
Profitabilitas & 35 & .03 & .29 & .0963 & .06344 \\
Ukuran & 35 & 26.09 & 32.08 & 28.88 & 1.6524 \\
Perusahaan & & & & 8 \\
nilai & & & & 3.655 & 2.4492 \\
perusahaan & 35 & .79 & 10.48 & 4 & 7 \\
Valid N & & & & & \\
(listwise) & 35 & & & & \\
\hline
\end{tabular}

Dari pengujian statistik deskriptif yang tersaji pada tabel 9 diketahui bahwa, pada variabel CSR diperoleh nilai minimum 0,5 , nilai maximum 0,72 , nilai rata-rata 0,1909 dengan deviasi sebesar 0,05705. Variabel profitabilitas memiliki nilai minimum 0,03 , nilai maximum 0,29 , nilai rata-rata 0,0963 dengan deviasi sebesar 0,06344 . Untuk variabel ukuran perusahaan diperoleh nilai minimum 26,09 , nilai maximum 32,08 , 
nilai rata-rata 28,8823 dengan deviasi 1,65248 . Sedangkan untuk variabel nilai perusahaan memiliki nilai minimum 0,79, nilai maximum 10,48, nilai rata-rata 3,6554 dengan deviasi 2,44927.

Uji Asumsi Klasik

\section{Uji Normalitas}

Dasar pengambilan keputusannya adalah jika nilai signifikansi kurang dari 0,05 maka variabel tidak terdistribusi normal.

Tabel 4.9 Uji Normalitas

\begin{tabular}{|ll|r|}
\hline \multicolumn{2}{|c|}{ One-Sample Kolmogorov-Smirnov Test } \\
\hline N & $\begin{array}{c}\text { Unstandard } \\
\text { ized } \\
\text { Residual }\end{array}$ \\
\hline Normal Parameters & Mean & 35 \\
& Std. & .0000000 \\
Most Extreme & Deviation & 1.04981257 \\
Differences & Absolute & .140 \\
& Positive & .140 \\
Kolmogorov-Smirnov Z & -.081 \\
Asymp. Sig. (2-tailed) & .831 \\
\hline a. Test distribution is Normal. & .495 \\
\hline
\end{tabular}

Hasil pengelolahan data penelitian dengan menggunakan uji Kolmogrov-Smirnov test yang tersaji pada tabel di atas sebesar 0,495 yaitu lebih besar dari 0,05 yang artinya menunjukkan bahwa data penelitian berdistribusi normal.

\section{Uji Heteroskedastisitas}

Penelitian ini menggunakan uji scatterplot untuk menguji gejala heteroskedastisitas. Cara mendeteksi ada tidaknya gejala heteroskedastisitas adalah dengan melihat ada tidaknya pola tertentu pada grafik scatterplot di sekitar nilai $\mathrm{X}$ dan $\mathrm{Y}$. Jika ada pola maka terjadi gejala heteroskedastisitas. Adapun hasil dari uji heteroskedastisitas adalah sebagai berikut:

\section{Gambar 4.1 Uji Heteroskedastisitas}

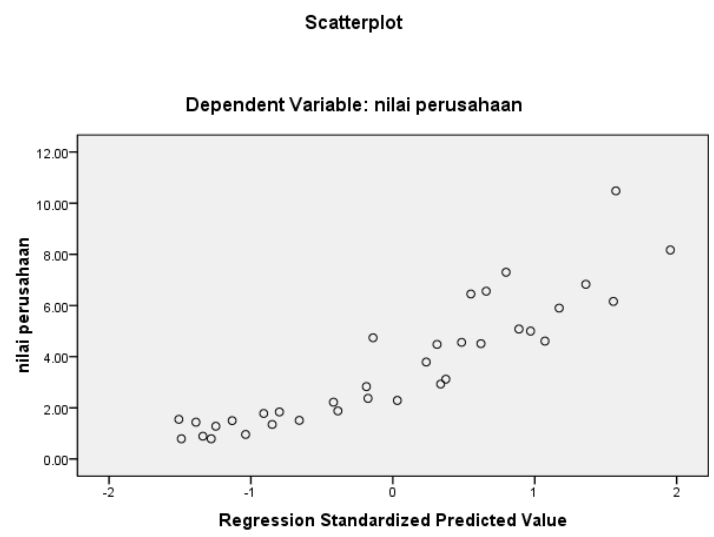

Berdasarkan output scatterplot di atas, titik-titik menyebar dan tidak membentuk pola yang jelas. Sehingga dapat disimpulkan bahwa tidak terjadi masalah heteroskedastisitas.

\section{Analisis Regresi Berganda}

Hasil analisis regresi berganda adalah berupa koefisien untuk masing-masing variabel independen.

Tabel 4.10 Koefisien Regresi Berganda Coefficients $^{\mathrm{a}}$

\begin{tabular}{|l|c|c|c|c|c|}
\hline \multirow{4}{*}{ Model } & \multicolumn{2}{|c|}{$\begin{array}{c}\text { Unstandardiz } \\
\text { ed } \\
\text { Coefficients }\end{array}$} & $\begin{array}{c}\text { Standardize } \\
\mathrm{d} \\
\text { Coefficients }\end{array}$ & \multirow{3}{*}{} & \\
\cline { 2 - 5 } & $\mathrm{B}$ & $\begin{array}{c}\text { Std. } \\
\text { Error }\end{array}$ & Beta & $\mathrm{t}$ & Sig. \\
\hline
\end{tabular}




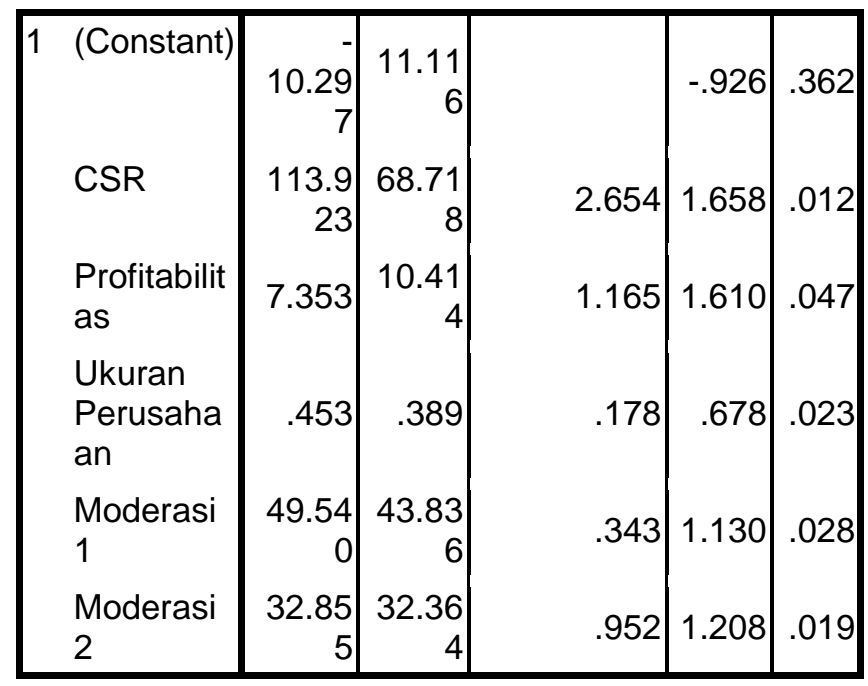

a. Dependent Variable: nilai perusahaan

Berdasarkan nilai koefisien yang ada pada tabel di atas maka dapat di simpulkan persamaan regresi sebagai berikut:

Dari hasil persamaan regresi berganda tersebut, masing-masing variabel independen dapat diinterpretasikan pengaruhnya terhadap nilai perusahaan sebagai berikut:

a. Konstanta (B) sebesar -10.297 menyatakan bahwa variabel independen konstan, maka nilai perusahaan adalah sebesar -10.297

b. Koefisien nilai $X_{1}$ sebesar 113.923 . Hal ini menunjukkan bahwa apabila terjadi peningkatan variabel $\mathrm{X}_{1}$ sebesar $1 \%$, maka akan menurunkan nilai perusahaan sebesar 113.923

c. Koefisien nilai $X_{2}$ sebesar 7.353. Hal ini menunjukkan bahwa apabila terjadi peningkatan variabel $X_{2}$ sebesar $1 \%$, maka akan menurunkan nilai perusahaan sebesar 7.353

d. Koefisien nilai $X_{3}$ sebesar 0.453 . Hal ini menunjukkan bahwa apabila terjadi peningkatan variabel $X_{3}$ sebesar $1 \%$, maka akan menurunkan nilai perusahaan sebesar -0.453

e. Koefisien nilai $M_{1}$ sebesar 49.540. Hal ini menunjukkan bahwa apabila terjadi peningkatan variabel $M_{1}$ sebesar $1 \%$, maka akan menurunkan nilai perusahaan sebesar 49.450

f. Koefisien nilai $\mathrm{M}_{2}$ sebesar 32.855. Hal ini menunjukkan bahwa apabila terjadi peningkatan variabel $\mathrm{M}_{2}$ sebesar $1 \%$, maka akan menurunkan nilai perusahaan sebesar 32.855

\section{Analisis Regresi Moderasi}

\section{Tabel 4.11 Koefisien Regresi Moderasi}

\begin{tabular}{|c|c|c|c|c|c|}
\hline \multicolumn{6}{|c|}{ Coefficients $^{a}$} \\
\hline \multirow[b]{2}{*}{ Model } & \multicolumn{2}{|c|}{$\begin{array}{c}\text { Unstandardiz } \\
\text { ed } \\
\text { Coefficients } \\
\end{array}$} & \multirow{2}{*}{\begin{tabular}{|c|}
$\begin{array}{c}\text { Standardiz } \\
\text { ed } \\
\text { Coefficient } \\
\text { s }\end{array}$ \\
Beta \\
\end{tabular}} & \multirow[b]{2}{*}{$t$} & \multirow[b]{2}{*}{ Sig. } \\
\hline & B & \begin{tabular}{|l|} 
Std. \\
Error
\end{tabular} & & & \\
\hline 1 (Constant) & $\begin{array}{r}- \\
10.297\end{array}$ & $\begin{array}{r}11.11 \\
6\end{array}$ & & -.926 & .362 \\
\hline CSR & $\begin{array}{r}113.92 \\
3\end{array}$ & $\begin{array}{r}68.71 \\
8\end{array}$ & 2.654 & $\begin{array}{r}1.65 \\
8\end{array}$ & .012 \\
\hline Profitabilitas & 7.353 & $\begin{array}{r}10.41 \\
4\end{array}$ & 1.165 & $\begin{array}{r}1.61 \\
0\end{array}$ & .047 \\
\hline $\begin{array}{l}\text { Ukuran } \\
\text { Perusahaan }\end{array}$ & .453 & .389 & .178 & .678 & .023 \\
\hline Moderasi 1 & 49.540 & $\begin{array}{r}43.83 \\
6\end{array}$ & .343 & $\begin{array}{r}1.13 \\
0\end{array}$ & .028 \\
\hline Moderasi 2 & 32.855 & $\begin{array}{r}32.36 \\
4 \\
\end{array}$ & .952 & $\begin{array}{r}1.20 \\
8 \\
\end{array}$ & .019 \\
\hline
\end{tabular}




\begin{tabular}{|c|c|c|c|c|c|}
\hline \multirow[b]{2}{*}{ Model } & \multicolumn{2}{|c|}{$\begin{array}{l}\text { Unstandardiz } \\
\text { ed } \\
\text { Coefficients }\end{array}$} & \multirow{2}{*}{\begin{tabular}{|c|}
$\begin{array}{c}\text { Standardiz } \\
\text { ed } \\
\text { Coefficient } \\
\text { s }\end{array}$ \\
Beta \\
\end{tabular}} & \multirow[b]{2}{*}{$\mathrm{t}$} & \multirow[b]{2}{*}{ Sig. } \\
\hline & B & \begin{tabular}{|l|} 
Std. \\
Error
\end{tabular} & & & \\
\hline 1 (Constant) & 10.297 & $\begin{array}{r}11.11 \\
6\end{array}$ & & -.926 & .362 \\
\hline CSR & $\begin{array}{r}113.92 \\
3\end{array}$ & $\begin{array}{r}68.71 \\
8\end{array}$ & 2.654 & $\begin{array}{r}1.65 \\
8\end{array}$ & .012 \\
\hline Profitabilitas & 7.353 & $\begin{array}{r}10.41 \\
4\end{array}$ & 1.165 & $\begin{array}{r}1.61 \\
0\end{array}$ & .047 \\
\hline $\begin{array}{l}\text { Ukuran } \\
\text { Perusahaan }\end{array}$ & .453 & .389 & .178 & .678 & .023 \\
\hline Moderasi 1 & 49.540 & $\begin{array}{r}43.83 \\
6\end{array}$ & .343 & $\begin{array}{r}1.13 \\
0\end{array}$ & .028 \\
\hline Moderasi 2 & 32.855 & $\begin{array}{r}32.36 \\
4\end{array}$ & .952 & $\begin{array}{r}1.20 \\
8\end{array}$ & .019 \\
\hline
\end{tabular}

a. Dependent Variable: nilai

perusahaan

Variabel CSR memiliki nilai sig sebesar 0.012, Profitabilitas memiliki nilai sig 0,047 sementara itu Moderasi 1 memiliki nilai sig 0,028. Kesimpulan yang bisa diperoleh dari hasil diatas adalah secara parsial CSR berpengaruh terhadap nilai perusahaan begitu juga profitabilitas secara parsial berpengaruh terhadap nilai perusahaan dan juga signifikan sebagai variabel moderating. profitabilitas sebagai variabel moderating antara CSR dengan nilai perusahaan menunjukkan hasil bahwa profitabilitas sebagai variabel moderating memperkuat pengaruh CSR dengan nilai perusahaan. Yang tadinya sebelum ada variabel moderating dengan hasil sig sebesar 0,047 namun setelah ada variabel moderating menunjukkan angka sig sebesar 0,028 yang mana semakin mendekati nilai signifikan. Jadi dapat disimpulkan bahwa profitabilitas merupakan variabel moderasi dari pengaruh CSR terhadap nilai perusahaan.

Begitu juga dengan variabel ukuran perusahaan memiliki nilai sig 0,023 sementara itu Moderasi 2 memiliki nilai sig 0,019. Kesimpulan yang bisa diperoleh dari hasil diatas adalah secara parsial CSR berpengaruh terhadap nilai perusahaan begitu juga ukuran perusahaan secara parsial berpengaruh terhadap nilai perusahaan dan juga signifikan sebagai variabel moderating. Ukuran perusahaan sebagai variabel moderating antara CSR dengan nilai perusahaan menunjukkan hasil bahwa ukuran perusahaan sebagai variabel moderating memperkuat pengaruh CSR dengan nilai perusahaan. Yang tadinya sebelum ada variabel moderating dengan hasil sig sebesar 0,023 namun setelah ada variabel moderating menunjukkan angka sig sebesar 0,019 yang mana semakin mendekati nilai signifikan. Jadi dapat disimpulkan bahwa ukuran perusahaan merupakan variabel moderasi dari pengaruh CSR terhadap nilai perusahaan.

\section{Uji Hipotesis}

1. Uji Koefisien Determinasi $\left(\mathbf{R}^{2}\right)$

Uji Koefisien determinasi di lakukan dengan tujuan untuk melihat sejauh mana variabel independen mampu menjelaskan variasi variabel dependen.

Tabel 4.12 Uji Koefisien Determinasi

Model Summary ${ }^{\mathrm{b}}$

\begin{tabular}{|c|c|c|c|c|c|c|c|c|c|}
\hline \multirow[b]{2}{*}{$\begin{array}{l}\text { Mode } \\
1\end{array}$} & \multirow[b]{2}{*}{$\mathrm{R}$} & \multirow[b]{2}{*}{$\begin{array}{c}\mathrm{R} \\
\text { Squar } \\
\mathrm{e}\end{array}$} & \multirow[b]{2}{*}{$\begin{array}{c}\text { Adjuste } \\
\mathrm{d} R \\
\text { Square }\end{array}$} & \multirow[b]{2}{*}{$\begin{array}{l}\text { Std. } \\
\text { Error of } \\
\text { the } \\
\text { Estimat } \\
\text { e }\end{array}$} & \multicolumn{5}{|c|}{ Change Statistics } \\
\hline & & & & & $\begin{array}{c}\text { R } \\
\text { Squar } \\
\text { e } \\
\text { Chan } \\
\text { ge }\end{array}$ & $\begin{array}{c}F \\
\text { Chang } \\
e\end{array}$ & $\begin{array}{c}\mathrm{df} \\
1\end{array}$ & $\begin{array}{c}\mathrm{df} \\
2\end{array}$ & $\begin{array}{c}\text { Sig. F } \\
\text { Chan } \\
\text { ge }\end{array}$ \\
\hline 1 & .913 & .834 & .806 & $\begin{array}{r}1.0794 \\
1\end{array}$ & .834 & $\begin{array}{r}29.21 \\
1\end{array}$ & & & .000 \\
\hline
\end{tabular}




\section{Model Summary}

\begin{tabular}{|c|c|c|c|c|c|c|c|c|c|}
\hline \multirow[b]{2}{*}{ Mode } & \multirow[b]{2}{*}{$\mathrm{R}$} & \multirow[b]{2}{*}{$\begin{array}{c}\mathrm{R} \\
\text { Squar } \\
\mathrm{e}\end{array}$} & \multirow[b]{2}{*}{$\begin{array}{c}\text { Adjuste } \\
\text { d R } \\
\text { Square }\end{array}$} & \multirow[b]{2}{*}{$\begin{array}{l}\text { Std. } \\
\text { Error of } \\
\text { the } \\
\text { Estimat } \\
e\end{array}$} & \multicolumn{5}{|c|}{ Change Statistics } \\
\hline & & & & & $\begin{array}{c}\text { R } \\
\text { Squar } \\
\text { e } \\
\text { Chan } \\
\text { ge }\end{array}$ & $\begin{array}{c}F \\
\text { Chang } \\
\text { e }\end{array}$ & $\begin{array}{c}\mathrm{df} \\
1\end{array}$ & $\begin{array}{l}\mathrm{df} \\
2\end{array}$ & $\begin{array}{l}\text { Sig. F } \\
\text { Chan } \\
\text { ge }\end{array}$ \\
\hline 1 & .913 & .834 & .806 & \begin{tabular}{|r|}
1.0794 \\
1
\end{tabular} & .834 & $\begin{array}{r}29.21 \\
\end{array}$ & & & .000 \\
\hline
\end{tabular}

a. Predictors: (Constant), Moderasi 2, Ukuran

Perusahaan, Profitabilitas, Moderasi 1, CSR

b. Dependent Variable:

nilai perusahaan

Berdasarkan tabel diatas dapat kita lihat bahwa nilai $\mathrm{R}^{2}$ adalah 0,834 hal tersebut berarti $83.4 \%$ variabel nilai perusahaan di pengaruhi oleh CSR, profitabilitas dan ukuran perusahaan.Sedangkan $16.6 \%$ di pengaruhi oleh variabel-variabel lain di luar persamaan.

\section{Uji Tingkat Signifikansi Simultan}

Tabel 4.13 Uji Tingkat Signifikan Simultan

ANOVA $^{\mathrm{D}}$

\begin{tabular}{|c|c|c|c|c|c|}
\hline Model & $\begin{array}{l}\text { Sum of } \\
\text { Squares }\end{array}$ & Df & $\begin{array}{c}\text { Mean } \\
\text { Square }\end{array}$ & $\mathrm{F}$ & Sig. \\
\hline $\begin{array}{ll}1 & \text { Regressio } \\
\mathrm{n}\end{array}$ & 170.175 & 5 & 34.035 & $\begin{array}{r}29.21 \\
1\end{array}$ & $.000^{\mathrm{a}}$ \\
\hline Residual & 33.789 & 29 & 1.165 & & \\
\hline Total & 203.964 & 34 & & & \\
\hline
\end{tabular}

a. Predictors: (Constant), Moderasi 2, Ukuran

Perusahaan, Profitabilitas, Moderasi 1, CSR

b. Dependent Variable: nilai perusahaan

Pada uji signifikansi simultan tingkat signifikan yang di gunakan dalam penelitian ini adalah $5 \%$ ( $p$ value 0.050). Hasil uji signifikansi (Uji F) memperlihatkan nilai $F$ hitung sebesar 29.211 dengan tingkat signifikan $0.000 \quad(<0.050)$ dengan demikian dapat di simpulkan bahwahCorporate Social Responsibility, profitabilitas, dan ukuran perusahaan berpengaruh pada nilai perusahaan.

\section{Uji Signifikan Parsial (t-test)}

Dasar penerimaan atau penolakan hipotesis dapat di lihat dari nilai signifikansinya. Variabel independen dikatakan memiliki pengaruh signifikansi terhadap variabel dependen apabila variabel independen tersebut memiliki nilai (sig) dibawah $0,05(<0,05)$

\section{Tabel 4.14 Uji Signifikan Parsial}

Coefficients $^{\mathrm{a}}$

\begin{tabular}{|c|c|c|c|c|c|}
\hline \multirow[b]{2}{*}{ Model } & \multicolumn{2}{|c|}{$\begin{array}{l}\text { Unstandardized } \\
\text { Coefficients }\end{array}$} & \multirow{2}{*}{\begin{tabular}{|c|}
$\begin{array}{c}\text { Standardi } \\
\text { zed } \\
\text { Coefficien } \\
\text { ts }\end{array}$ \\
Beta \\
\end{tabular}} & \multirow[b]{2}{*}{$t$} & \multirow[b]{2}{*}{ Sig. } \\
\hline & B & $\begin{array}{l}\text { Std. } \\
\text { Error }\end{array}$ & & & \\
\hline 1 (Constant & -10.297 & 11.116 & & .926 & .362 \\
\hline CSR & $\begin{array}{r}113.92 \\
3\end{array}$ & 68.718 & 2.654 & $\begin{array}{r}1.65 \\
8\end{array}$ & .012 \\
\hline $\begin{array}{l}\text { Profitabilit } \\
\text { as }\end{array}$ & 7.353 & 10.414 & 1.165 & $\begin{array}{r}1.61 \\
0\end{array}$ & .047 \\
\hline
\end{tabular}




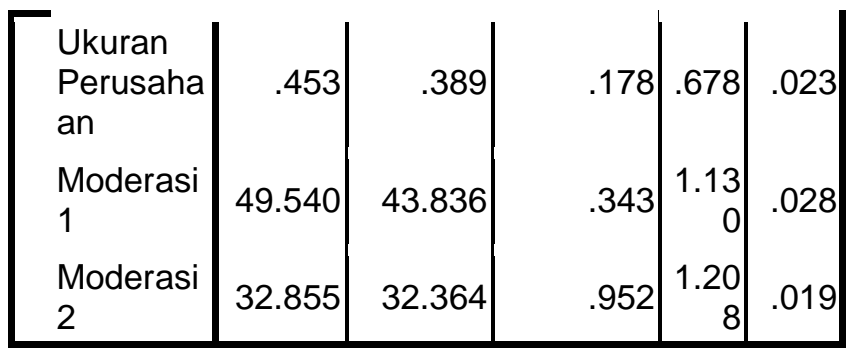

a. Dependent Variable: nilai

perusahaan

Dari tabel diatas hasil pengujian secara parsial menunjukkan bahwa secara parsial Corporate Social Responsibility, Profitabilitas, dan ukuran perusahaan dianggap berpengaruh terhadap nilai perusahaan. Hal ini ditunjukkan oleh nilai signifikan Corporate Social Responsibility sebesar 0,012 yang berarti lebih kecil dari 0,05. Begitu juga dengan variabel profitabilitas berpengaruh signifikan terhadap nilai perusahaan karena angka signifikannya sebesar 0.047 yang berarti lebih kecil dari 0.05 . dan untuk variable ukuran perusahaan secara parsial di anggap berpengaruh karena nilai signifikannya sebesar 0.023 yang artinya lebih kecil dari 0.05 .

\section{HASIL DAN PEMBAHASAN}

1. Pengaruh Corporate Social Responsibility terhadap Nilai Perusahaan $\left(\mathbf{H}_{\mathbf{1}}\right)$

Hipotesis pertama ini menyatakan bahwa Corporate Social Responsibility berpengaruh positif terhadap nilai perusahaan. Berdasarkan hasil analisis regresi yang di sajikan pada tabel 14, diperoleh koefisien regresi untuk variabel CSR sebesar 2.654 dan nilai t hitung sebesar 1.658 dengan signifikansi 0,012 yang nilai signifikansinya lebih kecil dari tingkat signifikansi $(\alpha)=5 \%$ atau 0,05 atau ternyata $p$ value $0,012<0,05$. Hal ini menunjukkan bahwa Corporate Social Responsibility berpengaruh positif dan signifikan terhadap nilai perusahaan, maka dengan demikian $\mathrm{H}_{1}$ diterima. Hasil penelitian ini sesuai dengan penelitian Rimba Kusumadilaga, Silvia Agustina, Sunardi Muji, Gusti Ayu Made Ervina Rosiana dan Gedhe Juliarsa, yang menyatakan CSR berpengaruh terhadap nilai perusahaan.

2. Pengaruh Corporate Social Responsibility terhadap nilai perusahaan dengan profitabilitas sebagai variabel moderating $\left(\mathrm{H}_{2}\right)$

Hipotesis kedua penelitian ini menyatakan bahwa Corporate Social Responsibility berpengaruh positif terhadap nilai perusahaan ketika profitabilitas perusahaan tinggi. Berdasarkan hasil analisis regresi moderasi 1 pada tabel 14, diperoleh nilai moderasi 1 sebesar 0.343 dan nilai t hitung sebesar 1,130 dengan signifikansi 0,048 . Karena nilai signifikansi lebih kecil dari 0,05 maka variabel moderasi 1 dianggap mampu mempengaruhi hubungan antara Corporate Social Responsibility dengan nilai perusahaan pada saat profitabilitas tinggi, dengan demikian $\mathrm{H}_{2}$ diterima. Hal ini sesuai dengan penelitian dari Ira Agustine, Silvia Agustina, Gusti Ayu Made Ervina dan Gede Juliarsa yang menyatakan variabel profitabilitas sebagai variabel moderating dapat memepengaruhi hubungan CSR dan nilai perusahaan.

3. Penagaruh Corporate Social Responsibility terhadap nilai perusahaan dengan ukuran perusahaan sebagai variabel moderating $\left(\mathrm{H}_{3}\right)$

Hipotesis ketiga ini menyatakan bahwa Corporate Social Responsibility berpengaruh positif terhadap nilai perusahaan ketika ukuran perusahaan tinggi. Berdasarkan hasil analisis moderasi 2 pada tabel 14, diperoleh nilai moderasi 2 sebesar -1.952 dan nilai t hitung sebesar -1.208 dengan signifikansi 0,049 karena nilai signifikansi lebih kecil dari 0,05 maka variabel moderating 2 mampu mempengaruhi hubungan antara Corporate Social Responsibility dengan nilai perusahaan pada saat ukuran perusahaan tinggi, dengan demikian $\mathrm{H}_{3}$ di terima. Hal ini sesuai dengan penelitian Sunardi Muji yang meyatakan bahwa ukuran perusahaan berpengaruh signifikan trhadap CSR dan nilai perusahaan.

\section{KESIMPULAN DAN SARAN}

Kesimpulan

Kesimpulan yang dapat diambil dari hasil penelitian ini adalah sebagai berikut :

a. Pengungkapan Corporate Social Responsibility berpengaruh terhadap nilai perusahaan karena CSR merupakan bentuk tanggung jawab perusahaan untuk memperbaiki masalah sosial dan lingkungan yang terjadi akibat aktivitas operasional perusahaan, oleh sebab itu CSR sangat berperan untuk meningkatkan nilai perusahaan, semakin tinggi tanggung jawab sosial perusahaan terhadap lingkungan masyarakat dan stakeholdemya maka nilai perusahaan akan semakin baik.

b. Profitabilias mempengaruhi tinggi reandahnya pengungkapan Corporate Social Responsibility terhadap nilai perusahaan, variabel profitabilitas sebagai variabel moderating dianggap dapat mempengaruhi hubungan CSR dan nilaiperusahaan. Dengan kata lain Corporate Social Responsibility dapat meningkatkan nilai perusahaan pada saat profitabilitas perusahaan tinggi, dan sebaliknya 
lemahnya pengungkapan CSR dapat menurunkan nilai perusahaan pada saat profitabilitas perusahaan rendah.

c. Ukuran perusahaan dapat memperkuat dan memperlemah Corporate Social Responsibility terhadap nilai perusahaan, variabel ukuran perusahaan sebagai variabel moderating ternyata dapat mempengaruhi hubungan CSR dan nilai perusahaan. Dengan kata lain meningkatnya nilai perusahaan oleh CSR dapat di pengaruhi juga oleh peningkatan yang terjadi pada ukuran Saran perusahaan.

Berdasarkan hasil analisis pembahasan serta beberapa kesimpilan dan keterbatasan pada penelitian ini, dapun saran-saran yang dapat diberikan melalui hasil penelitian ini agar mendapatkan hasil yang lebih baik, yaitu:

1. Penelitian selanjutnya di harapkan bisa menambah beberapa variabel seperti Good Corporate Governance (GCG) sebagai variabel bebas dalam pengaruhnya terhadap nilai perusahaan.

2. Peneliti selanjutnya di harap bisa menguji kedua variabel moderating secara bersama sama secara berkesinambungan sehingga bias menciptakan hipotesis baru.

3. Peneliti selanjutnya diharapkan bisa menggunakan lebih banyak perusahaan dengan sampel yang lebih luas pada perusahaan manufaktur yang terdaftar di BEI

4. Penelitian selanjutnya diharapkan menggunakan rentang waktu yang lebih lama dari penelitian ini.

5. Penelitian selanjutnya diharapkan menggunakan variabel lain selain moderasi, seperti variable intervening.

\section{DAFTAR PUSTAKA}

Agustina. 2013. Pengaruh Profitabilitas dan Pengungkapan Corporate Social Responsibility Terhadap Nilai Perusahaan (Studi Empiris pada Perusahaan Manufaktur yang Terdaftar di Bursa Efek Indonesia). Universitas Negeri Malang

Agustine. 2014. Pengaruh Corporate Social Responsibility Terhadap Nilai Perusahaan. Finesta, Vol. 2, No. $1,42-47$.

Corporate Social Responsibility (http://id.wikipedia.org/wiki/Tanggung jawab sosial perusahaan.com). Diakses 20 Juni 2016.

Corporate Social Responsibility terhadapa kinerja perusahaan (www.journal.unair.ac.id/filerPDF/Utama\%20(2)\%20Subagyo\%20Adam\%20(Optimalisasi\%20CSR).d oc). Diakses 20 Juni 2016.

Devinisi Corporate Social Responsibility (http://www.mallenbaker.net/csr/CSRfiles/definition.Html). Diakses 20 Juni 2016.

Dewi \& Wirajaya. 2013. Pengaruh Struktur Modal, Profitabilitas dan Ukuran Perusahaan Pada Nilai Perusahaan. E-Jurnal Akuntansi Universitas Udayana, No. 4.2:358-372

Hermuningsih. 2013. Pengaruh Profitabilitas, Growth Oppoetunity, Sruktur Modal terhadap Nilai Perusahaan Pada Perusahaan Publik di Indonesia. Buletetin Ekonomi Moneter dan Perbankan.

Horne \& Wachowicz. 2009. Prinsip-Prinsip Manajemen Keuangan. Salemba Empat.Jakarta.

Lisa,Oyong. 2012. Asimetri Informasi Dan Manajemen Laba: Suatu Tinjauan Dalam Hubungan Keagenan. Jurnal WIGA Vol. 2 No. 1.

Kasmir, 2009. Pengantar Manajemen keuangan. PT. Raja Grafindo persada: Jakarta.

Kusumadilaga. 2010. Pengaruh Corporate Social Responsibility Terhadap Nilai Perusahaan Dengan Profitabilitas Sebagai Variabel Moderating. Universitas Diponegoro

Muji, 2012. pengaruh CSR terhadap nilai perusahaan dengan ukuran perusahaan sebagai variabel moderating. Jurnal Akuntansi.

Prasetyorini. 2013. Pengaruh Ukuran Perusahaan, Leverage, Price Earning Ratio dan Profitabilitas Terhadap Nilai Perusahaan. Jurnal IImu Manajemen, Vol. 1, No. 1

Rosiana \& Juliarsa. 2013. Pengaruh Pengungkapan CSR Terhadap Nilai Perusahaan Dengan Profitabilitas Sebagai Variabel Pemoderasi. E-Jurnal Akuntansi Universitas Udayana 5.3:723-738.

Sartono,Agus. 2010. Manajemen Keuangan Teori dan Aplikasi, Edisi Keempat. BPFE: Yogyakarta.

Silondae, \& Fathoeddin, 2010. Aspek Hukum Dalam Ekonomi Bisnis. Mitra Wacana Media: Malang.

Standarisasi tanggung jawab sosisal perusahaan http://ati.staff.gunadarma.ac.id/Downloads/files/8200/Standarisasi\%25252BTanggung\%25252BJawa b\%25252BSosial\%25252BPerusahaan\%25252B\%25252B28\%25252BJan\%25252B08.pdf

Subekti. Pengaruh Corporate Social Responsibility dan Good Corporate Governance Terhadap Nilai perusahaan (Pada perusahaan yang Terdaftar di Bursa Efek Indonesia).

Umbara \& suryana. 2014. Pengaruh Pengungkapan Tanggung Jawab Sosial Pada Nilai Perusahaan. Ejurnal Akuntansi Universitas Udayana No. 9.2:410-424

Weston \& Copeland, 2007. Manajemen Keuangan. Erlangga: Jakarta. 